\title{
re_LER_macbeth: a presença do texto no ensino do teatro
}

re_READ_macbeth: the presence of text
in theater teaching

Heloise Baurich Vidor ${ }^{1}$ 


\section{Resumo}

Este artigo discute a presença do texto nos processos de ensino e aprendizagem de teatro, colocando em interface os campos do teatro, da literatura e da educação. Práticas de leitura em performance (Zumthor, 2007), associadas à abordagem lúdica proveniente do fazer teatral, delineiam as ações de encontro com o texto na aula: ler, proferir, escutar e ver, ao invés de dramatizar ou encenar. Através de três experiências com o texto Macbeth, a autora discute o percurso proposto aos jogadores, que partiu da ênfase na teatralidade - atuação e criação de cenas - para a ênfase na leitura do texto.

Palavras-chave: Literatura; Shakespeare; Leitura; Jogo

\section{Abstract}

This article discusses the presence of text in the processes of teaching and learning theater, putting in interface the fields of theater, literature and education. In performance reading practices (Zumthor, 2007), associated with the playful approach derived from the theater making, outline the actions that provide the meeting with the text in the classroom: reading, speaking, listening and seeing, rather than dramatizing or acting. Through three experiences with the text Macbeth, the author discusses the proposal made to the players, which started from the emphasis on theatricality - performance and creation of scenes - to the emphasis on reading the text.

Keywords: Literature; Shakespeare; Reading; Game

ISSN: 1414.5731

E-ISSN: 2358.6958

${ }^{1}$ Profa. Dra. Adjunta do Departamento de Artes Cênicas e do Programa de Pós-Graduação em Teatro (PPGT/CEART - UDESC). heloisebvidor@gmail.com 
As considerações que teço neste artigo estão relacionadas a aspectos abordados na tese Leitura e Teatro: aproximação e apropriação do texto literário ${ }^{2}$. 0 ponto de partida da pesquisa foi o desejo de revisar e explorar formas de trabalhar com o texto nas aulas de teatro, tanto na universidade como em outros contextos educacionais. Esclareço que, no âmbito desta reflexão, a palavra "texto" refere-se à unidade linguística formada por palavras, frases e orações, que expressa um conteúdo com um valor semântico dado pelo resultado de um emissor que se comunica através de signos com um receptor que os decodifica (Luaiza, B. A.; Gonzalez, R. M. P, 2008).

No teatro, o texto previamente escrito por um autor continua ocupando seu lugar, ainda que tenha perdido a hegemonia como elemento deflagrador da cena. Segundo Lehmann (2009), a partir das vanguardas históricas e do surgimento da cultura midiática, as condições basilares do teatro se modificaram, e isso diz respeito, por exemplo, à função e status que o texto ocupa nos processos criativos, afirmando que nas últimas três décadas houve, entre outros fatores, a "redução do peso da participação do elemento verbal (em seu sentido mais estrito) na experiência teatral" (Lehmann, 2009, p. 88). Deste fato decorre que, no trabalho com os atores, práticas corporais passaram a ser bastante valorizadas entre os elencos, muitas vezes em detrimento do trabalho com a palavra.

No campo das relações entre teatro e educação, o trabalho com o texto apresenta-se, sobremaneira, como um grande desafio. Neste contexto, e sob uma perspectiva histórica, a grande conquista das últimas quatro décadas foi o trabalho com a improvisação, que surgiu na contramão do texto decorado e rigidamente marcado pelos professores. Essa foi (e em alguma medida ainda é) a forma como se trabalhou o teatro com não atores. Eixo central do trabalho teatral, com diversos encaminhamentos, através de diferentes metodologias, a improvisação fruto do jogo entre os atores continua sendo a base da abordagem de trabalho para muitos professores.

Importantes perspectivas no que se refere à visão pedagógica de aliar a improvisação ao texto literário via jogo teatral ou via modelo de ação foram abertas com o trabalho das professoras Ingrid Koudela (2010) e Maria Lucia Pupo (2005), conformando caminhos alternativos à situação relatada e, em ambos os casos, procedimentos são apontados. No entanto, a verticalidade no ato da leitura, associada ou não ao jogo teatral e sua dimensão cênica, ainda foi pouco explorada. Neste sentido, o enfrentamento com o texto, o trabalho minucioso com o mesmo e a ênfase na sua apropriação pelo aluno ainda se apresentam como campo fértil para a experimentação e a reflexão.

Durante o acompanhamento dos estagiários do curso de Licenciatura em Teatro, pude observar que, quando o texto dramático, narrativo ou poético estava presente nos processos de ensino, a opção recorrente de muitos professores era a de solicitar aos alunos uma leitura prévia ao trabalho prático, que muitas vezes não acontecia, e utilizar o tema como estímulo inicial para a construção de outro texto, de autoria coletiva, criado a partir de improvisações. Ou seja, o trabalho pautava-se na recria-

\footnotetext{
2 Programa de Pós Graduação em Artes Cênicas. Linha de pesquisa: Pedagogia do Teatro, Teatro e Educação. Orientadora: Dra. Maria Lúcia de Souza Barros Pupo. Bolsa de fomento: FAPESC. A tese está publicada com o mesmo título: VIDOR, H. B. Leitura e Teatro: aproximação e apropriação do texto literário. São Paulo: Hucitec, 2016.
} 
ção do texto do autor pelo aluno, de modo que a fábula era mantida ou parcialmente mantida, mas o texto original não.

Estas constatações abriram espaço para algumas suposições sobre o problema, como a dificuldade do aluno com a leitura/letramento, dificuldade esta anterior ao momento da experiência teatral propriamente dita; a dificuldade com um tipo de atividade que requer tempo lento, esforço, certa imobilidade física, ainda mais se for o caso de ler um texto na íntegra, já que há uma tendência atual de se recorrer a adaptações ou versões dos textos narrativos e/ou dramáticos nas aulas de literatura (e de teatro), na tentativa de facilitar o trabalho do leitor.

Com isso, podemos pensar que se o professor parte do princípio de que os alunos não gostam de ler, ele supõe que em um processo de teatro não teria sentido insistir na leitura, pois estes, da mesma forma, passariam a não gostar de teatro. Sem saber como conduzir esse processo de apropriação do texto de forma que transcenda a abordagem relacionada à técnica de atuação - que não se sustenta em uma perspectiva de trabalho com não atores - e que, ao mesmo tempo, se diferencie da forma como a literatura é trabalhada nas aulas de língua portuguesa que, segundo os pesquisadores João Wanderley Geraldi (2011), Yolanda Reyes (2012) e María Teresa Andruetto (2012), é uma forma "escolarizada" e desinteressante, o professor de teatro prefere não se debruçar sobre esta tarefa.

A proposta aqui apresentada e discutida parte da aproximação dos campos do teatro, da leitura e da literatura, buscando alternativas para o enfrentamento das dificuldades apontadas. E propõe o contato dos participantes com os textos através das ações de ler, vocalizar o que se lê, escutar e ver, distanciando-se das ações de atuar e recitar. Macbeth (2009), de William Shakespeare, foi um dos textos lidos dentro desta perspectiva e será aqui referenciado por se tratar da terceira aproximação a ele que buscou explorar a leitura em detrimento da atuação e/ou da encenação.

\section{Texto (ou quando as palavras estão tramadas)}

"Chama-se texto o conjunto dos enunciados linguísticos submetidos à análise: o texto é então uma amostra de comportamento linguístico que pode ser escrito ou falado" (Dubois, 2006). Do latim, textus tem como significado tecido. Este significado, tecido, já nos remete à sua característica de trama e nos mostra que, entre os fios que são tramados, podemos encontrar espaços que podem estar mais ou menos ajustados.

Seguindo, a palavra texto comporta ainda algumas definições: 1 . Conjunto de palavras, de frases escritas. 2. Obra escrita considerada na sua redação original e autêntica (por oposição a sumário, tradução, notas, comentários). 3. Qualquer texto destinado a ser dito ou lido em voz alta. 4. Excerto de língua seja escrita ou falada, de qualquer extensão, que constitui um todo unificado. 5. Toda expressão ou conjunto de expressões que a escrita fixou (Ferreira, 2010).

Insisto na imagem do tecido tramado e recorro à palavra textura, do latim textura, cujas definições são: 1. Ato ou efeito de tecer. 2. Tecido, trama, contextura (Ferreira, 2010), e acabo por colocá-la junto à palavra texto, justamente para que não haja dúvida sobre a definição que estou considerando para a presente discussão. 
O texto como pluralidade possível e potente estabelece um campo de diálogo e terra fértil para a criação teatral e serve de base para que a inspiração e a discussão germinem no processo criativo. Desta forma, proponho pensar no texto como um tecido, cuja trama apresenta espaços - os fios tramados são as palavras. O conjunto de fios tramados origina um todo unificado, escrito ou falado.

O despertar das palavras dormentes no texto escrito exige a ação de um leitor. Como se dá a ação do leitor com o texto? Estou me remetendo aqui aos textos ficcionais e atribuímos a eles a ideia de trama, de contextura. Nesta trama, e de acordo com o que aponta Wolfgang Iser no artigo O jogo do texto (1996), considero o leitor como agente que confere ao texto a textura no exato momento em que a leitura ocorre. Entendo, assim, que o texto não é "expressão de algo outro", anterior e independente dele; seu sentido se engendra nessa ação que incorpora a imaginação do leitor. Isto é possível porque "o texto contém um grau interno de indeterminação que o distingue de um teorema ou de uma mensagem", conforme esclarece Luiz Costa Lima na apresentação da obra de Iser (Lima, 2002, p. 25).

A indeterminação é como um efeito de estranhamento que se acentua nos textos ficcionais e "é motivado pela presença na cena textual de lugares vazios" (Lima, 2002 , p. 26). Estes podem ser definidos como relações não formuladas entre as diversas camadas do texto e suas várias possibilidades de conexão, ou seja, de trama. Os lugares vazios, em suma, caracterizam a estrutura do texto literário como uma articulação com furos que exige do leitor mais do que a capacidade de decodificação. A decodificação diz respeito ao domínio da língua. O vazio exige do leitor uma participação ativa através da imaginação.

Neste sentido, para Iser, a participação do leitor impossibilita o entendimento tradicional de uma interpretação única do texto. "Como os lugares vazios estimulam a indeterminação e esta, em vez de tão só dificultar o reconhecimento das expectativas do leitor, as põe em questão, abre-se uma relação potencialmente tensa e provocativa" (Iser, 2002, p. 26). A tensão é gerada porque o leitor tenta aplacar o estranhamento numa tentativa de "normalizar" o efeito da indeterminação, através de uma "intervenção interpretativa" única que, para este teórico, destrói a experiência literária.

Assim, a "intervenção interpretativa" desejável se traduziria na consciência do leitor de seu papel ativo, papel que implica uma coautoria na fruição da obra, e que exige disponibilidade e abertura para arriscar-se como criador de sentidos. Isto em lugar de uma postura de passividade na recepção do texto, como se o mesmo fosse portador de um sentido estanque, encerrado em uma única e correta possibilidade significativa.

Portanto, para fruir o texto o leitor é convidado a participar de um jogo que estabelece algumas regras básicas: a primeira é aceitar que não está diante de uma interpretação única, nem correta, e que o jogo que o texto propõe pode estar longe das expectativas que o leitor tem por suas referências prévias; a segunda é que o leitor aceite firmar o contrato no qual o mundo textual há de ser concebido não como realidade, mas como se fosse realidade; e a terceira é que assuma uma posição ativa de modo a preencher os espaços vazios com a sua imaginação.

O termo jogo, segundo Roger Callois analisa no ensaio Os jogos e os homens 
(1990), traz à tona as ideias de limite, liberdade e invenção, e remete, também, à ideia de amplitude, de facilidade de movimentos, de diversão. Ou seja, a fruição do texto literário, pautada pelo jogo com o texto, segundo este raciocínio, pode ser tomada como uma ação que transita entre o limite e a liberdade, em um movimento divertido do leitor que deve preencher seus espaços vazios. Teoricamente, parece uma tarefa fácil e agradável, mas de acordo com Silvia Castrillón (2011) a fruição do texto literário exige um esforço, nem sempre prazeroso, a ser duramente conquistado, haja vista a quantidade de programas de incentivo à leitura que existem na atualidade e que buscam constantemente formas de enfrentar este grande desafio.

Em meu caso, que não estou vinculada ao campo da teoria literária, outra questão que se coloca é: quais são os textos que se prestam ao jogo proposto por Iser? Entendo que são os textos literários. Mas quais são os critérios utilizados para se classificar um texto como sendo literatura? E na sequência: se a fruição da literatura exige esforço por parte do leitor para conquistar o prazer (que nem sempre ocorre) e um empenho de educadores e escritores para que novos leitores possam desfrutar deste bem, por que insistir neste propósito? Qual é a preciosidade que há na literatura que merece a somatória de esforços?

\section{A presença da literatura no ensino - entre a arte e a pedagogia}

Literatura, do latim litteratura, significa arte de escrever e deriva da palavra latina littera, que significa "letra" (Houaiss, 2014). Se considerarmos o que propõe o escritor e professor Antônio Candido, no artigo intitulado O direito à literatura (1995), o texto literário ou a literatura "são todas as criações de toque poético, ficcional ou dramático em todos os níveis de uma sociedade, em todos os tipos de cultura, desde o que chamamos folclore, lenda, chiste, até as formas mais complexas e difíceis da produção escrita das grandes civilizações" (Candido, 1995, p. 174). Com esta definição bastante abrangente, o autor passa a cercar a questão que deu título a seu artigo: quem tem direito à literatura?

Candido inicia sua argumentação defendendo que a experiência da fabulação é experimentada por todos os seres humanos, pois ela está presente no sonho (que é assegurado pelo sono) e no estado de vigília, por isso este universo fabular é familiar a cada um de nós, sejamos analfabetos ou eruditos, de modo que todos nós necessitamos deste universo que supera qualquer relação com condições sociais e intelectuais. Posto isso, ele traça um paralelo entre o equilíbrio que o sono com sonho [grifo nosso] dá ao psiquismo e o equilíbrio social que pode ser obtido com a literatura. Seguindo este raciocínio, se ninguém pode passar vinte e quatro horas sem mergulhar no universo da ficção e da poesia, a literatura no sentido amplo que o autor lhe confere passa a ser uma necessidade universal, cumprindo um papel salutar à humanização e às relações sociais. Por humanização o autor entende:

$\mathrm{O}$ processo que confirma no homem aqueles traços que reputamos essenciais, como o exercício da reflexão, a aquisição do saber, a boa disposição para com o próximo, o afinamento das emoções, a capacidade de penetrar nos problemas da vida, o senso de beleza, a percepção da complexidade do mundo e dos seres, o cultivo do humor. A literatura desenvolve em nós a quota de humanidade na me- 
dida em que nos torna mais compreensivos e abertos para a natureza, a sociedade, o semelhante (Candido, 1995, p. 180).

Se a literatura é ficção, fabulação e poesia e, portanto, uma necessidade própria a todos os seres humanos, e se ela atua nos aspectos considerados humanizadores, organizando nossa visão de mundo e dando concretude aos nossos sentimentos, parece clara a sua preciosidade e o motivo pelo qual devemos insistir na sua fruição, ainda que, volta e meia, sejamos levados a justificar sua importância. E por que isso ocorre?

Antonio Candido discute a fruição da literatura a partir da forma de organização da sociedade, que a restringe ou amplia, dependendo do local ocupado pelo indivíduo em termos da estratificação social. Nas sociedades igualitárias, "o pressuposto é que todos devem ter a possibilidade de passar dos níveis populares para os níveis eruditos como consequência normal da transformação de estrutura, prevendo-se a elevação sensível da capacidade de cada um graças à aquisição cada vez maior de conhecimentos e experiências" (Candido, 1995, p. 188). Em contrapartida, tomando como exemplo a sociedade brasileira, em que se mantém com clareza a estratificação das possibilidades, nos deparamos com a ideia de que as classes populares estariam privadas de encontrar prazer com a leitura de obras eruditas de autores como Machado de Assis ou Mário de Andrade. A desigualdade presente na sociedade brasileira traz outras consequências que se relacionam com o alto índice de analfabetismo e com as condições precárias de sobrevivência, que acabam não favorecendo a atividade da leitura como lazer, e estas consequências persistem ao longo dos anos. Este quadro sofreu alterações, já que podemos constatar que não é somente a divisão de classes que interfere na fruição da literatura. Há um fator essencial, não considerado por Candido, que é o espaço crescente ocupado pelas mídias eletrônicas nos últimos vinte anos, fato que fez com que o desinteresse pela leitura afetasse todas as classes sociais. De qualquer forma, um dos obstáculos, segundo este autor, para diminuir o abismo entre os níveis popular e erudito é a falta de oportunidade e não a incapacidade [grifo nosso]. A falta de oportunidade de contato com as obras literárias, populares e eruditas, independentemente dos fatores sociais e econômicos, impede que o processo de prazer diante da literatura seja experimentado. Ou seja, esta é uma condição basilar para tratar tanto a fruição da literatura "como uma necessidade universal que deve ser satisfeita sob pena de mutilar a personalidade" (Candido, 1970, p. 186), quanto a destruição das barreiras da estratificação social, que, segundo o autor, no caso dos grandes clássicos, podem "redimir as distâncias impostas pela desigualdade econômica, pois têm a capacidade de interessar a todos e, portanto, devem ser levados ao maior número" (Candido, 1970, p. 189).

Ainda que eu me situe em um lugar distante daquele ocupado pelos escritores e estudiosos da literatura, considero-me ao mesmo tempo próxima da realidade que teima em se mostrar desigual na estratificação social e etária da fruição literária, observando esta realidade nas aulas de teatro que ministro e acompanho. Assim, busco formas de lidar na prática com impasses que afloram no momento de escolha do texto a ser lido e/ou encenado na aula de teatro. Além de levar em conta o tema, procuro incorporar uma ideia que me é cara por apresentar um critério que me pare- 
ceu fundamental, além dos já mencionados, e que se traduz na fala da atriz francesa Gislaine Drahy (2011) quando ela diz que os textos que nos tocam verdadeiramente são aqueles que nos "atravessam" e, ao nos "atravessarem", tocam o outro.

Ou seja, é importante que o texto apresente espaços vazios a serem preenchidos pela ação do leitor, como propõe Iser (1996), que traga uma abordagem temática que nos faça pensar sobre nossa própria vida e sobre o mundo no qual estamos inseridos - a literatura como interrogação sobre o mundo (Andruetto, 2013) e que, ao mesmo tempo, seja provocador de uma reação física no receptor, na medida em que atravessa seu corpo. Para tratarmos desta "reação física do receptor", nos remetemos a Paul Zumthor, linguista suíço, que no livro Performance, recepção, leitura (2007) diz: "o corpo é o peso sentido na experiência que faço dos textos. Meu corpo é a materialização daquilo que me é próprio, realidade vivida e que determina minha relação com o mundo" (Zumthor, 2007, p. 23). O autor reforça a ideia de que a leitura de um texto literário causa necessariamente uma reação física no leitor, vinculada ao prazer. É o prazer experimentado que se constitui no critério principal de poeticidade, além de outros que se relacionam com o discurso e o contexto no qual o discurso funciona. Parece-nos que o desafio é propiciar o processo de que fala Antonio Candido, que é "a elevação sensível da capacidade de cada um graças à aquisição cada vez maior de conhecimentos e experiências", e aceitar que a passagem de uma criação popular para uma erudita possa encontrar no caminho obras de uma "poeticidade parcial", mas que são fundamentais para alimentar o desejo de ler (Candido, 2005, p. 190). O registro no corpo da reação experimentada na leitura deste tipo de obra é o que interessa, se pensarmos que este mesmo leitor pode vir a descobrir o mesmo prazer em obras consideradas eruditas, se estas lhe forem disponibilizadas em algum momento de sua vida. A presença do texto no contexto do ensino traz à tona o papel da literatura para o exercício da alteridade, já que a ação de debruçar-se sobre um texto de ficção como leitor ou, no caso do teatro, como ator ou diretor, coloca explicitamente o enfrentamento com o pensamento do outro. Conforme Maria Lúcia Pupo defende em seu livro Entre o Mediterrâneo e o Atlântico - uma aventura teatral (2005, p. 4), "mergulhar num texto de ficção é mergulhar em outra lógica, é experimentar outras identidades, outros pensamentos, outras existências, o que implica naturalmente um poderoso exercício de alteridade". Assim, especialmente em processos educacionais, penso que o professor de teatro deve levar em conta as questões mencionadas, procurando driblar as dificuldades e insistir no trabalho com o texto escrito na escola e fora dela, pois, como aconselha Tzvetan Todorov, no texto A literatura em perigo (2012),

[...] é necessário incluir as obras no grande diálogo entre os homens, iniciando desde a noite dos tempos e do qual cada um de nós, por mais ínfimo que seja, ainda participa. [...] A nós, adultos, nos cabe transmitir às novas gerações essa herança frágil, essas palavras que ajudam a viver melhor (Todorov, 2012, p. 94).

Os aspectos mencionados anteriormente - a oportunidade de contato com a obra literária, o movimento de supressão das barreiras da estratificação social para a fruição de obras consideradas eruditas, a empatia pelos textos - foram disparadores para o delineamento do projeto artístico-pedagógico criado a partir da obra de 
William Shakespeare, MACBETH. Ele ganhou o título re_LER_macbeth, e será apresentado e discutido a seguir.

\section{re_LER _ macbeth - a literatura em performance}

re_LER_macbeth toma por base os estudos de Paul Zumthor, através da consulta às obras A letra e a voz (1993), Performance, recepção, leitura (2007) e Introdução à poesia oral (2010), com destaque para alguns aspectos relacionados à presença da voz na ação de leitura do texto ou, segundo ele, o texto "encarnado", ou seja, em performance, e o termo performance é utilizado em lugar de oralidade, pois performance incorpora os gestos e o espaço, além da voz.

A aproximação ao texto Macbeth - que se dá pela terceira vez - tem, portanto, o objetivo de verticalizar o corpo a corpo (Oliveira, 2009) com esta obra de Shakespeare, através das ações de ler, ler em performance, escutar e ver, de forma individual e coletiva, no âmbito intimo, privado ou público, sempre com o texto em mãos. A estas ações, propõe-se a inserção de pequenas regras e de movimentos corporais sutis durante a leitura, abrindo espaço para o lúdico, sem comprometer o contato do leitorjogador com o texto, de modo que o teatral vá se delineando através da observação destas ações em processo.

O intuito desta experimentação é insistir no demorar-se nas palavras tramadas, com idas e vindas a elas, em uma perspectiva espiralada e repetitiva, que crie espaço para o compartilhamento das impressões durante a sua ocorrência. Ou seja, fugir da dramatização do texto (ainda que seja um texto dramático), fugir da criação de um espetáculo, fugir de qualquer tentativa de representação de personagens por parte dos participantes e fugir de uma discussão teórica sobre a obra. A ideia é criar oportunidade de fruição da literatura, incorporando a dimensão afetiva que o corpo-voz e a situação coletiva podem suscitar no leitor/ouvinte/espectador, com um viés artístico-pedagógico.

O primeiro encontro com Macbeth se deu em 2009, quando realizei com estudantes de graduação da Licenciatura em Teatro um experimento cênico chamado Da ambição à loucura ${ }^{3}$. Este experimento explorou, através da metodologia do process drama ${ }^{4}$, os temas da ambição, da loucura e do impacto das profecias e a ênfase na teatralidade. Várias cenas foram criadas pelos participantes e o texto foi trazido em fragmentos, representados por mim (professora e atriz), participando juntamente com os estudantes.

Decorrente desta experiência, uma segunda aproximação do texto levou à criação do espetáculo solo inspirado no modelo de "aula espetáculo" uma lady: MACBE$T H^{5}$, cuja ideia central é partir de uma aula em que surgem contrapontos aqui e ali oriundos do texto de Shakespeare. Um modo de abordar a obra através dos vários olhares simultâneos e das várias vozes que a compõem. Tratando-se de uma aula

\footnotetext{
${ }^{3}$ Este experimento foi realizado em parceria com a Profa. Dra Beatriz Ângela Vieira Cabral.

${ }^{4}$ Process drama, também conhecido por drama ou drama in education, é uma metodologia inglesa de ensino, utilizada no ensino do teatro. Ver: CABRAL, B.A.V. Drama como método de ensino. São Paulo: Hucitec, 2006 e VIDOR, H.B. Drama e Teatralidade: o ensino do teatro na escola. Porto Alegre: Mediação, 2010.

${ }^{5}$ O espetáculo estreou no SESC - Joinville em 2010 e segue em cartaz, tendo percorrido várias cidades do Estado de Santa Catarina, além de São Paulo/SP e Dourados/MS
} 
no presente, a cenografia, os figurinos e a ambientação refletem essa condição, e não aquela da ficção proposta pela fábula da peça. Embora trajes e objetos de época sejam mobilizados quando necessários ou adequados, a proposta se situa na fronteira entre presença e representação, diminuindo progressivamente os aspectos propriamente teatrais. Em uma lady: $M A C B E T H$, tanto a atuação, quanto a relação com o espaço cênico buscam neutralidade, atemporalidade e certo tom narrativo, não revelando explicitamente quando é a atriz que está falando ou quando é algum dos personagens do texto. No desenrolar desta aula-espetáculo, alguns trechos do texto são intencional e insistentemente repetidos, ora atuados, ora lidos, com diferentes intenções e sob diferentes perspectivas (através da aparição de seus principais personagens: Macbeth e Lady Macbeth), compartilhando e assumindo a dificuldade de contar esta história tão rica de detalhes e acontecimentos extraordinários.

Com esta terceira aproximação, re_LER_macbeth pretende retomar o contato com o texto, com o objetivo de radicalizar o ato de ler. A ideia é partir da leitura e retornar a ela de modo que impressões possam ser compartilhadas e ações realizadas durante $o$ ato de ler coletivamente na aula. Estas ações podem ter texturas diferentes: musicais, corporais, visuais, textuais e as práticas coletivas serão conduzidas através da proposição de regras previamente acordadas. Um exemplo de combinação de regras:

Todos sentados em roda ou semicírculo. Todos com uma cópia do texto em mãos. Um leitor levanta-se e, com o objeto livro nas mãos, inicia a leitura. Ele pode (ou não) se movimentar pelo centro da roda. No momento que desejar parar de ler, ele pode passar o livro para outro leitor que deve assumir a leitura, ou propor alguma ação. Ao final do texto ou de cada capítulo, é solicitado ao grupo que, um por vez, escreva uma palavra-síntese no quadro (sala de aula), cartolina ou parede. A palavra pode estar relacionada ao texto lido ou à atividade proposta, dependendo do caso. A atividade durará o tempo da aula. E será retomada do ponto em que foi interrompida a leitura.

A opção por limites claros, delimitações precisas e caracterizadas como regras de um jogo, acontece por termos já a clareza de que os limites expandem, ao invés de restringir as possibilidades de contato com o que se lê e/ou faz. A intenção é criar um espaço de jogo com o texto, com o espaço e com as pessoas.

\section{Considerações sobre o texto na aula - para além da pedagogia do teatro}

A presença da literatura nos processos de ensino, que, como afirma o filósofo da educação Fernando Bárcena (2012), faz parte da arte das mediações, abre espaço para que o aprendizado ocorra a partir de uma experiência estética. O mediador, aquele que conhece previamente o texto e propõe a forma como ele será lido, criando a situação de aprendizagem a partir de certos recursos e objetivos, aceita correr o risco de não obter um resultado pré-determinado. Ou seja, aceita que o desenrolar do processo se dê entre ele e os participantes, mediados pela obra/projeto, decifran- 
do os sentidos e construindo conhecimento enquanto o caminho é trilhado.

Quando optei pela condução do trabalho com a leitura em performance (Zumthor, 2007), me ocorreu que, para aqueles que não gostassem de ler, não tivessem o hábito da leitura, iniciar a proposta lendo da forma usual - individual e silenciosa - poderia ser um elemento de resistência e afastamento, principalmente com adolescentes. Queria garantir o contato de TODOS os participantes com o texto, por isso a opção de disponibilizar os livros e as fotocópias de modo que o momento silencioso e solitário pudesse acontecer durante e após o encontro coletivo.

A descoberta do texto em performance leva à partilha das reações durante o processo da leitura: a curiosidade sobre o desenrolar da narrativa, as surpresas diante dos acontecimentos. Portanto, ao mesmo tempo em que esta circunstância imprime uma relação de extrema atenção e certa tensão, ela mobiliza os participantes, que se surpreendem com a obra e com as reações dos colegas diante dela.

Sabemos que o conhecimento de um texto nesta situação coletiva, por um lado limita a liberdade e a intimidade criadas quando o leitor está sozinho com ele, explorando-o à sua maneira (Manguel, 2010; Pettit, 2013). Mas sabemos também que neste tipo de leitura outros sentidos são ativados e podem mobilizar o leitor, contribuindo tanto para que ele experimente o prazer da fruição estética quanto para a ampliação da rede de sentidos contida no texto (Zumthor, 2007; Bajour, 2013). A opção de recepção em performance não invalida a recepção silenciosa, penso que elas são complementares.

No caso de re_LER_macbeth, durante o encontro, o receptor pôde comparar o texto por duas vias: auditiva e visual. E, na medida em que a obra havia sido disponibilizada a todos os jogadores, eles teriam a possibilidade de retornar a ela quando e como desejassem. Uma sensação de incompletude foi relatada pelos participantes ao final do encontro. Esta sensação era previsível, já que o habitual no contexto teatral seria partir para a atuação dos personagens e a criação das cenas após um primeiro contato com o texto (ou com parte dele). Acredito também que a mesma sensação esteja relacionada ao esforço que a leitura exige - o preenchimento dos espaços vazios pela imaginação, a articulação dos sentidos.

Em linhas gerais, o objetivo foi deixar uma margem de espaços "(ainda) vazios" (Iser, 1996) ou "a serem preenchidos" em relação ao todo, ou seja, ao texto e à proposta de lê-lo. Deixar em aberto, em suspenso, pode ser frustrante por um lado, mas por outro, pode ser uma forma de garantir um lugar para as reverberações, fugindo da lógica explicativa, mencionada por Jacques Rancière (2010) em O mestre ignorante - cinco lições sobre emancipação intelectual. Em Macbeth, violência, ambição, morte e loucura são temas trazidos à baila, de forma que o professor e os alunos podem lidar com eles, expressando-se através de materialidades artísticas, propostas durante a leitura, além da reflexão sobre estes mesmos temas no desenrolar do processo pedagógico. De acordo com Cabral (2010), entre a ética e a estética, a relação de aprendizagem decorrente de uma experiência com a obra de Shakespeare na escola - e aqui podemos estender a outros autores clássicos e a outros contextos de ensino -, oferece a oportunidade de reflexão sobre a consistência e a coerência dos valores subjacentes às ações das personagens, tentando esclarecer e questionar os princípios que regem aquelas ações, relativizados pelo universo ficcional. A partir 
daí, há uma abertura para repensarmos as formas de ler a literatura, procurando fugir daquela que a aborda como "uma atividade escolarizada, fragmentada, uma prática essencialmente analítica, informativa, cujo objetivo último seria o de classificar autores e obras" (Oliveira, 2009, p.1).

Para finalizar, reforço que um projeto embasado na leitura de literatura deve considerar duas premissas fundamentais: o ato de ler dá ao leitor o direito de pular páginas, de abandonar a leitura e depois retomar, ou até mesmo de não ler; a leitura do texto literário - plural, aberto, polissêmico - não condiz com uma abordagem que tende a estabelecer um sentido para ele. Assim, a intenção é que o texto seja o mediador no encontro entre leitores, ouvintes e espectadores, que se alternam nestes papéis, propiciando uma experiência compartilhada de fruição de literatura e passível de adquirir teatralidade.

\section{Referências}

ANDRUETTO, M. T. Por uma literatura sem adjetivos. Tradução: Carmen Cacciacarro. São Paulo: Pulo do Gato, 2012.

BAJOUR, C. Ouvir nas entrelinhas. O valor da escuta nas práticas de leitura. Tradução de Alexandre Morales. São Paulo: Editora Pulo do Gato, 2012.

BÁRCENA, F. El aprendiz eterno. Filosofía, educación y el arte de vivir. Buenos Aires: Miño y Dávila editores, 2012.

CABRAL, B. A. V. Drama como método de ensino. São Paulo: Hucitec, 2006.

Estética do dissenso em processos coletivos. In: Ensaios em cena. NAVAS, C.; ISAACSSON, M.; FERNANDES, S. (Orgs.). Salvador: ABRACE; Brasília, DF: CNPQ, 2010. p. 94-105.

CALLOIS, R. Os jogos e os homens. A máscara e a vertigem. Tradução José Garcez Palha. Lisboa: Ed. Cotovia, 1990.

CANDIDO, A. O direito à literatura. In: Vários Escritos. 1995. Disponível em: http:// culturaemarxismo.files.wordpress.com. Acesso em 14 de abril de 2014.

CASTRILLÓN, S. O direito de ler e escrever. Tradução Marcos Bagno. São Paulo: Editora Pulo do Gato, 2011.

DRAHY, G. Le plaisir de l'esquisse. In: Agôn Revue des arts de la scène. 2011. Disponível em: http://agon.ens-lyon.fr/index.php?id=1866. Acesso em 02/08/12

DUBOIS, J. et al. Dicionário de linguística. Tradução de Izidoro Blikstein. São Paulo: Cultrix, 2006. 
LEHMANN, H. Just a word on a page and there is drama. Apontamentos sobre o texto pósdramático. In: MOSTAÇO, E; OROFINO, I; BAUMGARTEN, S; COLLAÇO, V. (Org.). Sobre Performatividade. Florianópolis: Letras Contemporâneas, 2009.

FERREIRA, A. B. H. Dicionário Aurélio de Língua Portuguesa. Curitiba. Ed. Positivo, 2010.

GERALDI, J. W. Práticas da leitura na escola. In: GERALDI, J. W (Org.). O texto na sala de aula. São Paulo: Ática, 2011.

HOUAISS, A. Grande dicionário Beta da Língua Portuguesa. Instituto Antônio Houaiss: UOL, 2014. Disponível para assinantes em: http://houaiss.uol.com. Acesso 24/05/2014.

ISER, W. O jogo do texto. In: LIMA, L. C. A literatura e o leitor. Textos de estética da recepção. Rio de Janeiro: Paz e Terra, 2002.

KOUDELA, I. Texto e Jogo. São Paulo: Perspectiva, 2010.

LIMA, L. C. A Literatura e o leitor. Textos de estética da recepção. Rio de Janeiro: Paz e Terra, 2002.

LUAIZA, B. A.; GONZALES, R. M. P. Definición y clasificación del texto desde una óptica de la didáctica de la lectura. Revista Año 10 n. 10, 2008. Disponível em www. aal. idoneos.com. Acesso em 05 jul. 2011.

MANGUEL, A. Uma história da leitura. Tradução de Pedro Maia Soares. São Paulo: Companhia das Letras, 2012.

OLIVEIRA, E. K. Corpo a corpo com o texto literário. Tese apresentada no Programa de Pós-Graduação do Instituto de Estudos da Linguagem da UNICAMP, Campinas, 2009. p. 1-167.

PETIT, M. Leituras. Do espaço íntimo ao espaço público. Tradução de Celina Olga de Souza. São Paulo: Editora 34, 2013.

PUPO, M. L. S. B. Entre o Mediterrâneo e o Atlântico. Uma aventura teatral. São Paulo: Perspectiva, 2005.

RANCIÈRE, J. O mestre ignorante. Cinco lições sobre emancipação intelectual. Tradução de Lilian do Valle. Belo Horizonte: Autêntica, 2010.

REYES, Y. Ler e brincar, tecer e cantar. Literatura, escrita e educação. Tradução de Rodrigo Petrônio. São Paulo: Pulo do Gato, 2012. 
SHAKESPEARE, W. Macbeth. Tradução de Manuel Bandeira. São Paulo: Cosac Naify, 2009.

TODOROV, T. A literatura em perigo. Tradução de Caio Meira. Rio de Janeiro: DIFEL, 2012.

VIDOR, H. B. Leitura e Teatro: aproximação e apropriação do texto literário. São Paulo, Ed. Hucitec, 2016

ZUMTHOR, P. A letra e a voz. A "literatura medieval". Tradução de Amálio Pinheiro (parte I) e Jerusa Pires Ferreira (parte II). São Paulo: Companhia das Letras, 1993.

Performance, recepção, leitura. Tradução de Jerusa Pires Ferreira e Suely Fenerich. São Paulo: Cosac Naify, 2007.

Introdução à poesia oral. Tradução de Jerusa Pires Ferreira, Maria Lúcia Diniz Pochat, Maria Inês de Almeida. Belo Horizonte: Editora UFMG, 2010.

Recebido em: 16/12/2016

Aprovado em: 30/03/2017 